\title{
Contribution of nitrous oxide emission from soil covered with plastic mulch film in vegetable field
}

\author{
Seiichi NiSHIMURA* ${ }^{*}$, Michio KOMADA*, Masako TAKEBE*, Shigeru TAKAHASHI*, \\ Seiichiro YOnEMURA**, Toshihiko KARASAWA*, Fumio SATO***, and Naoto KATO* \\ $\left(\begin{array}{c}* \text { NARO Agricultural Research Center, 3-1-1 Kannondai, Tsukuba, Ibaraki 305-8666, Japan } \\ * * \text { National Institute for Agro-Environmental Sciences, 3-1-3 Kannondai, Tsukuba, Ibaraki 305-8604, Japan } \\ * * * \text { NARO Institute of Vegetable and Tea Science, 3-1-1 Kannondai, Tsukuba, Ibaraki 305-8666, Japan }\end{array}\right)$
}

\begin{abstract}
The effects of soil mulching on the emission of nitrous oxide $\left(\mathrm{N}_{2} \mathrm{O}\right)$, a major greenhouse gas, from arable fields have rarely been investigated to date. In a previous study, we showed that a significant amount of $\mathrm{N}_{2} \mathrm{O}$ is emitted to the atmosphere from an arable field in which soil is covered with plastic mulch films; $\mathrm{N}_{2} \mathrm{O}$ is emitted both by permeation through the mulch films and by horizontal diffusion to the adjacent furrow soil surface. We continued measuring the $\mathrm{N}_{2} \mathrm{O}$ flux from a field grown to lettuce and carrots for two years. With the results of our previous study, we also estimated the contribution of $\mathrm{N}_{2} \mathrm{O}$ emitted during soil mulching to the cumulative emission. In winter, the contribution of $\mathrm{N}_{2} \mathrm{O}$ emission during soil mulching was low, ranging from 4 to $12 \%$. In contrast, in summer, the contribution of $\mathrm{N}_{2} \mathrm{O}$ emission during soil mulching after fertilization was high, ranging from 41 to $66 \%$ of the cumulative emission. Among these, the contribution of $\mathrm{N}_{2} \mathrm{O}$ emission by permeation through the mulch film was found to be particularly important, which ranged from 33 to $53 \%$ of the cumulative emission. These results indicate that $\mathrm{N}_{2} \mathrm{O}$ emission during soil mulching largely contributes to cumulative emission.
\end{abstract}

Key words: Furrow, Gas permeance, Nitrous oxide, Plastic mulch film, Soil gas diffusion.

\section{Introduction}

Covering ridge soil with plastic mulch films for cultivating crops is a major agricultural practice implemented worldwide. One main purpose of soil mulching is to keep soil temperature and water content high, at levels suitable for cultivating crops. Another purpose is to restrict arable weed growth. Soil mulching is also conducted prior to crop cultivation to reduce arable weeds and/or pathogenic microorganisms during the succeeding crop cultivation period. In this practice, often called 'soil solarization', the soil surface is continuously covered tightly with plastic film during the hot season. Thus, the temperature just below the mulch film increases markedly so that seeds and seedlings of

Received; March 8, 2013.

Accepted; December 12, 2013.

${ }^{\dagger}$ Corresponding Author: ssnn@affrc.go.jp

DOI: 10.2480/agrmet.D-13-00008 weeds and pathogenic microorganisms are expected to be severely damaged (Katan and Devay, 1991).

Nitrous oxide $\left(\mathrm{N}_{2} \mathrm{O}\right)$ is a major greenhouse gas which has a 298 -fold higher global warming potential than $\mathrm{CO}_{2}$ for a period of 100 years (Forster et al., 2007). It is produced in soil by various soil microbial species as a byproduct of nitrification and an intermediate product of denitrification (Bouwman, 1990; Hutchinson and Davidson, 1993). Fertilized agricultural soil is recognized as one of the major sources of $\mathrm{N}_{2} \mathrm{O}$.

Nitrous oxide production in soil generally increases under conditions of moderate or relatively high temperature and water contents, high inorganic $\mathrm{N}$ and organic matter contents, and low $\mathrm{O}_{2}$ concentration. Since soil covered with plastic mulch films just after fertilization is generally exposed to such conditions, a significantly high amount of $\mathrm{N}_{2} \mathrm{O}$ may be produced in the soil and emitted to the atmosphere. However, as described in the 2006 IPCC Guidelines for National 
Greenhouse Gas Inventories (De Klein et al., 2006), the dynamics of $\mathrm{N}_{2} \mathrm{O}$ production and transport in soil covered with plastic mulch films have rarely been investigated to date, since no methods of measuring the $\mathrm{N}_{2} \mathrm{O}$ flux have been established yet.

In a previous study, we revealed that a significant amount of $\mathrm{N}_{2} \mathrm{O}$ is emitted to the atmosphere from a field during soil mulching, both by permeation through mulch films and by horizontal diffusion to the adjacent furrow soil surface (Nishimura et al., 2012). In this study, we showed detailed seasonal changes in $\mathrm{N}_{2} \mathrm{O}$ flux over two years in a field grown to lettuce and carrots. We estimated the cumulative $\mathrm{N}_{2} \mathrm{O}$ emission from the entire field including both ridge and furrow soils. The contribution of $\mathrm{N}_{2} \mathrm{O}$ emitted during soil mulching to the cumulative emission was shown for the first time.

\section{Materials and Methods}

\subsection{Outline of experimental field}

The $\mathrm{N}_{2} \mathrm{O}$ flux in the field was measured from December 2009 to January 2012 in an experimental field $\left(36^{\circ} 01^{\prime} \mathrm{N}, 140^{\circ} 06^{\prime} \mathrm{E}\right)$ at the NARO Agricultural Research Center in Japan. The soil type in the field was volcanic acid soil (Andisols), and the surface layer $(0$ to $15 \mathrm{~cm}$ ) had a clay loam texture. The bulk density of the topsoil at a depth of $0-5 \mathrm{~cm}$ was $0.65 \mathrm{Mg} \mathrm{m}^{-3}$, and the soil $\mathrm{pH}$ in $\mathrm{H}_{2} \mathrm{O}$ was 6.3. The $\mathrm{C}$ and $\mathrm{N}$ contents of the topsoil $\left(0^{-} 5 \mathrm{~cm}\right.$ depth $)$ were $42 \mathrm{mg} \mathrm{C}$ g soil $^{-1}$ and $3.9 \mathrm{mg} \mathrm{N}$ g soil ${ }^{-1}$, respectively.

Table 1 shows the outline of the vegetable cultivation, the types and amounts of the applied fertilizer, and the vegetable yields. The field was grown to vegetables twice a year: lettuce (Lactuca sativa L., cultivar; Steady) in winter and carrots (Daucus carota L., cultivar; Koyo-2) in summer. Lettuce plants were grown under a transparent plastic tunnel to keep the area inside warm. We developed two treatments using differently applied fertilizers. One involved plots applied with a commercial compound organic fertilizer (Agret673, Asahi Industries Group, Japan for lettuce; Agret666, Asahi Industries Group, Japan for carrots), hereafter referred to as OF plots. The other involved plots applied with poultry manure compost and fish meal (as supplemental application for carrots), hereafter referred to as PM plots. Note that no fertilizer was applied to the OF plots in the summer of 2010 to investigate the effect of residual nutrients in the soil on the succeeding carrot growth. The lettuce yield ranged from 4.27 to $7.12 \mathrm{~kg} \mathrm{~m}^{-2}$, and the carrot yield ranged from 4.91 to $6.29 \mathrm{~kg} \mathrm{~m}^{-2}$.

Prior to the lettuce cultivation, the ridge soil was

Table 1. Outline of fertilization, crop cultivation and soil mulching practice of the experimental field.

\begin{tabular}{|c|c|c|c|c|c|}
\hline $\begin{array}{l}\text { Treat- } \\
\text { ment }\end{array}$ & $\begin{array}{l}\text { Type of } \\
\text { fertiliz- } \\
\text { er }\end{array}$ & $\begin{array}{l}\text { Date and amount of } \mathrm{N} \text { fertiliza- } \\
\text { tion }\left(\mathrm{kg} \mathrm{N} \mathrm{ha}^{-1}\right)^{*}\end{array}$ & Soil mulching ${ }^{\dagger}$ & $\begin{array}{l}\text { Vegetable cultivation period } \\
\text { (seeding/transplanting- } \\
\text { harvest) }\end{array}$ & $\begin{array}{l}\text { Vegetable } \\
\text { yield }(\mathrm{kg} \\
\left.\mathrm{m}^{-2}\right)^{\ddagger}\end{array}$ \\
\hline \multirow[t]{4}{*}{ OF } & Com- & $09 / 12 / 17(285)$ & $09 / 12 / 17-10 / 01 / 14$ & lettuce $(10 / 01 / 25-10 / 04 / 26)$ & 5.97 \\
\hline & mercial & (no fertilization) & $10 / 06 / 15^{-10 / 07 / 19}$ & carrot $(10 / 07 / 20-10 / 12 / 07)$ & 4.91 \\
\hline & organic & $11 / 01 / 11(135)$ & & lettuce $\left(11 / 01 / 26^{-11 / 04 / 27)}\right.$ & 5.17 \\
\hline & $\begin{array}{l}\text { fertiliz- } \\
\text { er }\end{array}$ & $11 / 06 / 16(90), 11 / 09 / 14(90)$ & $11 / 06 / 16^{-11 / 07 / 20}$ & carrot $(11 / 07 / 21-11 / 11 / 09)$ & 6.19 \\
\hline \multirow[t]{4}{*}{$\mathrm{PM}$} & Poultry & $09 / 12 / 17(285)$ & $09 / 12 / 17-10 / 01 / 14$ & lettuce $(10 / 01 / 25-10 / 04 / 26)$ & 4.27 \\
\hline & manure & $10 / 06 / 15(90), 10 / 09 / 22\left(120^{\S}\right)$ & $10 / 06 / 15^{-10 / 07 / 19}$ & carrot $(10 / 07 / 20-10 / 12 / 07)$ & 5.23 \\
\hline & com- & $11 / 01 / 11(360)$ & & lettuce $(11 / 01 / 26-11 / 04 / 27)$ & 7.12 \\
\hline & post & $11 / 06 / 16(90), 11 / 09 / 14\left(120^{\S}\right)$ & $11 / 06 / 16^{-11 / 07 / 20}$ & carrot $(11 / 07 / 21-11 / 11 / 09)$ & 6.29 \\
\hline
\end{tabular}

\footnotetext{
*, represented by total $\mathrm{N}$ per unit area of ridge

$\dagger$, period with imperforate mulch film maintained as tight soil surface cover

$\ddagger$, represented by fresh weight of edible biomass (lettuce, headed aboveground biomass; carrot, root biomass) per unit area of ridge

$\S$, applied with fish meal instead of poultry manure compost
} 
covered with a black plastic (polyethylene) mulch film $(0.02 \mathrm{~mm}$ thick $)$ just after fertilization for the lettuce. For the first lettuce cultivation, the mulch film was placed on Dec. 17, 2009 and was maintained as a tight soil surface cover without perforation until it was perforated on Jan. 15, 2010 for the transplanting of lettuce seedlings. The perforated mulch film was kept in the field thereafter and was removed on Jun. 15, 2010 (just before the next mulch film application in summer). For the second lettuce cultivation, the mulch film was placed on Jan. 11, 2011 and was immediately perforated for the transplanting of lettuce seedlings. The perforated mulch film was kept in the field thereafter until it was removed on Apr. 27, 2011 (just after the lettuce harvest). The diameter of each round hole made by perforation was about $5 \mathrm{~cm}$. From June to July in 2010 and 2011, the ridge soil was covered with a transparent plastic (polyethylene) mulch film $(0.02$ $\mathrm{mm}$ thick) just after fertilization (except for the OF plots in 2010) for the succeeding carrot cultivation. In the OF plots from June to July in 2010, the ridge soil was also covered with the transparent plastic mulch film, although it was not fertilized. The mulch film was maintained as a tight soil surface cover without perforation and was then removed for the carrot seeding. The depth of plowing was about $15 \mathrm{~cm}$. The ridge was $12 \mathrm{~m}$ in length and $1.2 \mathrm{~m}$ in width. The furrow between ridges (distance from the edge of a ridge to that of the adjacent ridge) was $0.6 \mathrm{~m}$ in width. Note that all of the fertilizers were applied only to the ridge soil, not to the furrow soil.

\subsection{Measurement of $\mathrm{N}_{2} \mathrm{O}$ flux and other data in field}

Nitrous oxide flux was measured at 2-24 day intervals throughout the experimental period. During the period without soil mulching, it was measured within the ridge for vegetable cultivation using the conventional closed-chamber method. A chamber consisting of gray polyvinyl chloride plates $(5 \mathrm{~mm}$ thick $)$ was placed on the ridge soil surface. The chamber had a basal area of $0.45 \mathrm{~m}^{2}(0.6 \mathrm{~m} \times 0.75 \mathrm{~m})$ and a height that varied from 0.2 to $0.5 \mathrm{~m}$, considering the growth of the vegetables inside the chamber. The general procedure for the flux measurement during the period with the perforated black mulch film (i.e., around the lettuce cultivation period) was the same as that during the period without the mulch film, as shown above. The reason for this is as follows. Hayashi et al. (2004) showed that the $\mathrm{N}_{2} \mathrm{O}$ flux from a soil surface covered with a plastic mulch film is not significantly suppressed when the perforated open area of the applied mulch film is not lower than $2.5 \%$ of the total covered area. This indicates that most $\mathrm{N}_{2} \mathrm{O}$ emitted from the ridge soil surface is immediately released to the atmosphere via the holes made by perforation. In this study, the total perforation area of the mulch film for the lettuce plants was about $2.5 \%$ of the total ridge area. Therefore, we assumed that the general results in the literature (Hayashi et al., 2004) can also be applied to this study.

During the period with the imperforate mulch films, the $\mathrm{N}_{2} \mathrm{O}$ flux measurement was conducted on the furrow soil surface between ridges using a chamber with a cross-sectional area of $0.18 \mathrm{~m}^{2}(0.6 \mathrm{~m} \times 0.3 \mathrm{~m})$ and a height of $0.1 \mathrm{~m}$. To obtain averaged flux data across the furrow, one $0.6-\mathrm{m}$ side of the chamber base was located tangent to the edge of the mulch cover, i.e., the other $0.6-\mathrm{m}$ side was located along the center of the furrow.

The gas sampling for the flux measurement was conducted between 9:30 and 12:00. The chamber was closed for $30 \mathrm{~min}$. The air inside the chamber was drawn three times, i.e., 1, 15, and 30 min after closing the chamber, using a syringe and was then immediately injected into a $25 \mathrm{~mL}$ evacuated glass vial. The air between the soil and the mulch film was also taken by directly pricking the mulch film with a needle connected to a syringe and injecting the air into an evacuated vial. The $\mathrm{N}_{2} \mathrm{O}$ concentration of the gas in the glass vial was analyzed using a gas chromatograph (GC-14A, Shimadzu, Japan) equipped with an electron capture detector and two switching valves for the preliminary separation of $\mathrm{N}_{2} \mathrm{O}$ from other gases.

Nitrous oxide flux was calculated as

$$
F=\rho \cdot \frac{V}{A} \cdot \frac{\Delta c}{\Delta t} \cdot \frac{P}{1013} \cdot \frac{273.15}{T},
$$

where $F$ denotes $\mathrm{N}_{2} \mathrm{O}$ flux $\left[\mu \mathrm{g} \mathrm{N}_{2} \mathrm{O}-\mathrm{N} \mathrm{m}^{-2} \mathrm{~h}^{-1}\right.$, and $\rho$, $V, A, \Delta c / \Delta t, P$, and $T$ denote gas density of $\mathrm{N}_{2} \mathrm{O}$ (= $1.25 \times 10^{9} \mu \mathrm{g} \mathrm{N}_{2} \mathrm{O}-\mathrm{N} \mathrm{m}^{-3}$ ), chamber volume $\left[\mathrm{m}^{3}\right]$, area of the chamber base $\left[\mathrm{m}^{2}\right]$, increasing rate of $\mathrm{N}_{2} \mathrm{O}$ concentration in the chamber $\left[10^{-6} \mathrm{~m}^{3} \mathrm{~m}^{-3} \mathrm{~h}^{-1}\right]$, air pressure (fixed to $1013 \mathrm{hPa}$ ), and air temperature [K], respectively.

Ambient air temperature data provided hourly by the Weather Data Acquisition System of the National In- 
stitute for Agro-Environmental Sciences, located about $700 \mathrm{~m}$ from the field, were used as $T$. The temperature of ridge soil at a depth of $5 \mathrm{~cm}$ was measured with a copper-constantan thermocouple with three replicates and recorded on a data logger (CR1000, Campbell Scientific Instruments, USA) at a 10-min interval.

Samples of ridge soil at a depth of $0^{-15} \mathrm{~cm}$ were collected at 7-57 day intervals during the experiment for the analysis of soil inorganic $\mathrm{N}$ content. The soil samples were collected randomly from eight locations in each plot, mixed, and then extracted with potassium chloride solution $(10 \% \mathrm{w} / \mathrm{w})$. Nitrate nitrogen $\left(\mathrm{NO}_{3}{ }^{-}\right.$$\mathrm{N}$ ) was analyzed by hydrazine reduction-sulfanilamide and $\alpha$-naphthylamine absorption spectrophotometry, and ammonium nitrogen $\left(\mathrm{NH}_{4}{ }^{+} \mathrm{N}\right)$ by indophenol blue absorption spectrophotometry in a continuousflow analyzer (QuAAtro2-HR, BL-TEC, Japan).

\subsection{Estimation of cumulative $\mathrm{N}_{2} \mathrm{O}$ emission}

The cumulative $\mathrm{N}_{2} \mathrm{O}$ emission from the entire field, including both the ridge and furrow soils, was estimated as follows. First, during the period without soil mulching, the cumulative $\mathrm{N}_{2} \mathrm{O}$ emission from the ridge soil was estimated by the trapezoidal integration of the measured $\mathrm{N}_{2} \mathrm{O}$ fluxes over the period. In a preliminary investigation, we observed that the background $\mathrm{N}_{2} \mathrm{O}$ flux (the $\mathrm{N}_{2} \mathrm{O}$ flux from bare soil without $\mathrm{N}$ fertilization) in this field generally falls within a low range, mostly lower than $10 \mu \mathrm{g} \mathrm{N} \mathrm{m}^{-2} \mathrm{~h}^{-1}$ (data not shown). Thus, in this study, we assumed the cumulative $\mathrm{N}_{2} \mathrm{O}$ emission from the furrow soil (except during the soil mulching) to be equal to the standard background emission from well-drained Japanese soil proposed by Akiyama et al. (2006), i.e., $1.0 \times D\left[\mathrm{~g} \mathrm{~N} \mathrm{ha}^{-1}\right]$, where $D$ denotes the number of days. For the period with the perforated mulch film, the cumulative $\mathrm{N}_{2} \mathrm{O}$ emission was estimated in the same way as that for the period without the mulch film.

Second, the cumulative $\mathrm{N}_{2} \mathrm{O}$ emission during the period with the imperforate mulch film was estimated as follows. The $\mathrm{N}_{2} \mathrm{O}$ emission from the furrow soil surface was estimated by the trapezoidal integration of the measured $\mathrm{N}_{2} \mathrm{O}$ fluxes over the period. The $\mathrm{N}_{2} \mathrm{O}$ flux by permeation through the mulch film was estimated on the basis of Fick's diffusion law, with data on the $\mathrm{N}_{2} \mathrm{O}$ concentration just below the mulch film, the soil temperature at $5 \mathrm{~cm}$ depth (measured in the field), and the gas permeance (permeation coefficient) of the mulch film. The gas permeance of the mulch film was meas- ured in a laboratory experiment. Then, the cumulative emission was also estimated by trapezoidal integration over the period. Our previous report (Nishimura et al., 2012) provides more details regarding the $\mathrm{N}_{2} \mathrm{O}$ flux measurement during the soil mulching with the imperforate mulch film. We could not measure the $\mathrm{N}_{2} \mathrm{O}$ concentration just below the mulch film or the soil temperature at $5 \mathrm{~cm}$ depth for all the plots; we could measure them only in the OF plots (winter 2009-2010 and summer 2011) and PM plots (summer 2010), respectively. We assumed that the soil temperatures and the ratios of $\mathrm{N}_{2} \mathrm{O}$ flux by permeation through the mulch film to that from the furrow soil surface were the same in both treatments, and estimated the $\mathrm{N}_{2} \mathrm{O}$ flux by permeation in the plots without the $\mathrm{N}_{2} \mathrm{O}$ concentration measurements using

$$
F_{p 2}=F_{f 2} \cdot F_{p 1} / F_{f 1},
$$

where $F_{p}$ and $F_{f}$ denote the $\mathrm{N}_{2} \mathrm{O}$ fluxes $\left[\mu \mathrm{g} \mathrm{N} \mathrm{m} \mathrm{N}^{-2}\right.$ ] by permeation through the mulch film and from the furrow soil surface. Subscript 1 denotes data on the plots with $\mathrm{N}_{2} \mathrm{O}$ concentration measurements just below the mulch film, while subscript 2 denotes data without such measurements.

The 'average' cumulative $\mathrm{N}_{2} \mathrm{O}$ emission of the field, including emissions from both the ridge and the furrow, was then estimated using

$$
N_{\text {tot }}=\left(w_{r} \cdot N_{r}+w_{f} \cdot N_{f}\right) /\left(w_{r}+w_{f}\right),
$$

where $N_{t o t}, N_{r}$ and $N_{f}$ denote the cumulative $\mathrm{N}_{2} \mathrm{O}$ emission $\left[\mathrm{kg} \mathrm{N} \mathrm{ha}^{-1}\right]$ from the whole field, from the ridge, and from the furrow, and where $w_{r}$ and $w_{f}$ denote the widths of the ridge $(=1.2 \mathrm{~m})$ and the furrow $(=0.6$ m), respectively. We used the estimated $\mathrm{N}_{2} \mathrm{O}$ emission by permeation through the mulch film as $N_{r}$ during the period with the imperforate mulch film.

Nitrous oxide flux often shows diurnal fluctuation, with higher values in the daytime and lower in nighttimes (Nishimura et al., 2005). In addition, gas permeance of a mulch film also changes according to diurnal change in ambient temperature (Nishimura et al., 2012). In this study, however, we did not conduct multiple flux measurements within a day due to insufficient manpower, and therefore we could not consider possible diurnal fluctuations in $\mathrm{N}_{2} \mathrm{O}$ flux when estimating cumulative emission. 


\section{Results and Discussion}

\subsection{Seasonal changes in $\mathrm{N}_{2} \mathrm{O}$ flux and soil inorganic $\mathrm{N}$ contents}

Seasonal change in $\mathrm{N}_{2} \mathrm{O}$ flux and soil $\mathrm{NH}_{4}^{+}$- and $\mathrm{NO}_{3}{ }^{-} \mathrm{N}$ contents are shown in Fig. 1. During the period with the imperforate mulch film, a significant amount of $\mathrm{N}_{2} \mathrm{O}$ was emitted from the soil surface of the furrow between ridges. During the period with the imperforate black mulch film in winter (from December 2009 to January 2010), the $\mathrm{N}_{2} \mathrm{O}$ flux from the furrow in the $\mathrm{OF}$ and $\mathrm{PM}$ plots gradually increased throughout the period to reach their maxima of 122 and $95 \mu \mathrm{g} \mathrm{N} \mathrm{m}{ }^{-2} \mathrm{~h}^{-1}$, respectively, 25 days after fertilization with mulching. During the period with the imperforate transparent mulch film in summer, $\mathrm{N}_{2} \mathrm{O}$ flux increased rapidly to reach its maximum within several days after fertilization with mulching. The maximum
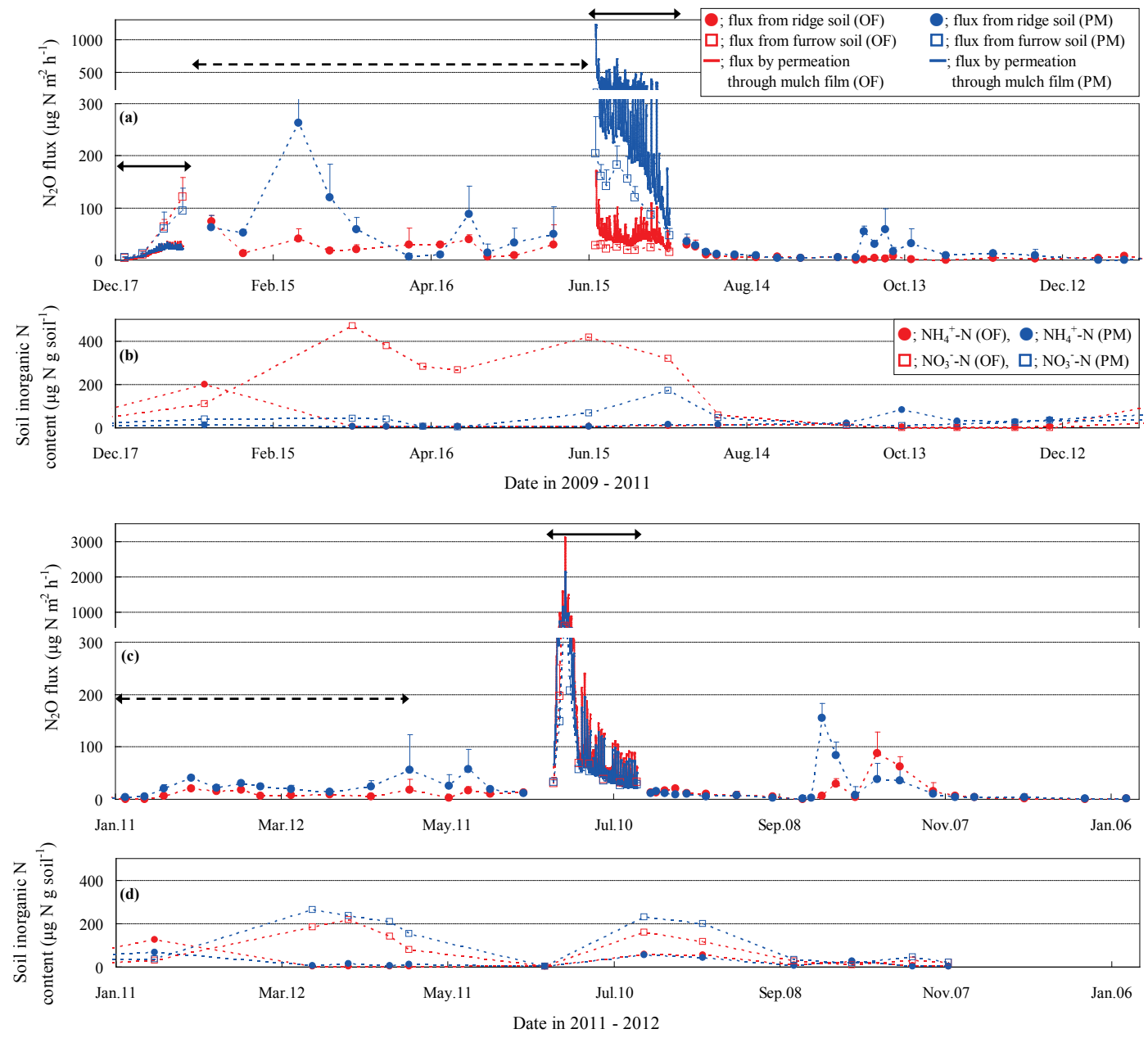

Fig. 1. Seasonal changes in (a, c) $\mathrm{N}_{2} \mathrm{O}$ flux from ridge and furrow soil surfaces and that by permeation through mulch film, and (b, d) soil $\mathrm{NH}_{4}{ }^{+}$- and $\mathrm{NO}_{3}{ }^{-}-\mathrm{N}$ contents.

The error bar in (a) and (c) shows the standard deviation of the measured $\mathrm{N}_{2} \mathrm{O}$ fluxes with three replicates.

The horizontal solid and dashed arrows show periods with the imperforate and perforated mulch films applied to the ridge soil, respectively.

Part of the data during the period with the imperforate mulch film is also shown in the report by Nishimura et al. (2012). 
$\mathrm{N}_{2} \mathrm{O}$ fluxes from the furrow were $205 \mu \mathrm{g} \mathrm{N} \mathrm{m} \mathrm{h}^{-1}$ in the PM plots in 2010, and 594 and $408 \mu \mathrm{g} \mathrm{N} \mathrm{m}^{-2} \mathrm{~h}^{-1}$ in the OF and PM plots, respectively, in 2011. Thereafter, the $\mathrm{N}_{2} \mathrm{O}$ flux gradually decreased. These increases in the $\mathrm{N}_{2} \mathrm{O}$ flux from the furrow soil surface are attributed to the horizontal diffusion of $\mathrm{N}_{2} \mathrm{O}$ produced in the fertilized ridge soil to the adjacent furrow soil surface. In the OF plots in 2010, the $\mathrm{N}_{2} \mathrm{O}$ flux from the furrow during the period with the imperforate mulch film in summer was remained low, of which the maximum was $30 \mu \mathrm{g} \mathrm{N} \mathrm{m}^{-2} \mathrm{~h}^{-1}$, presumably because no fertilizer was applied to the plots.

The estimated $\mathrm{N}_{2} \mathrm{O}$ flux by permeation through the black mulch film in winter was lower than that from the furrow soil surface, of which the maxima were 36 and $33 \mu \mathrm{g} \mathrm{N} \mathrm{m}^{-2} \mathrm{~h}^{-1}$ in the OF and PM plots, respectively. In contrast, the $\mathrm{N}_{2} \mathrm{O}$ flux by permeation through the transparent mulch film was extremely high in summer, of which the maxima reached 1230 in the PM plots in 2010, and 3120 and $2130 \mu \mathrm{g} \mathrm{N} \mathrm{m}^{-2} \mathrm{~h}^{-1}$ in the OF and PM plots in 2011, respectively. In the OF plots in 2010, the $\mathrm{N}_{2} \mathrm{O}$ flux by permeation was much lower than that in the PM plots, presumably because no fertilizer was applied, although it reached $169 \mu \mathrm{g} \mathrm{N} \mathrm{m}^{-2} \mathrm{~h}^{-1}$ at maximum. In addition, a remarkably large diurnal fluctuation in the $\mathrm{N}_{2} \mathrm{O}$ flux by permeation through the mulch film was found. This indicates a large diurnal variation in the flux according to the significant change in the gas permeance of the mulch film caused by a diurnal change in soil temperature. In the daytime on sunny days in summer, the soil temperature at $5 \mathrm{~cm}$ depth under the mulch film ranged mostly from 40 to $50{ }^{\circ} \mathrm{C}$ (cf., Nishimura et al., 2012). The gas permeance of the mulch film significantly increased under an extremely high temperature below the mulch film, which caused the high $\mathrm{N}_{2} \mathrm{O}$ flux by permeation.

Soil temperature during the period with the imperforate mulch film in winter was generally kept suitable for moderate progress of nitrification. Although soil temperature during the period with the imperforate mulch film in summer was quite high (with a daily maximum of $40-50{ }^{\circ} \mathrm{C}$ ), it still may not have been sufficient to cause significant inactivation of nitrification. Volumetric soil water content was kept stable (24-33\%) throughout the periods with the imperforate mulch film both in winter and in summer, which is also suitable for progress of nitrification. Oxygen concentration in the soil air did not become lower than
$12 \%$ for the entire experimental period, which did not indicate suitable condition for significant enhancement of denitrification. All of these environmental conditions indicated that the $\mathrm{N}_{2} \mathrm{O}$ in the mulch-covered soil was mainly produced via nitrification, and that the contribution of $\mathrm{N}_{2} \mathrm{O}$ production via denitrification was low. Specific data on these environmental factors and more detailed discussion on the processes of the $\mathrm{N}_{2} \mathrm{O}$ production in the mulch-covered soil are also described in our previous report (Nishimura et al., 2012).

During the rest periods without the mulch film or with the perforated mulch film, the $\mathrm{N}_{2} \mathrm{O}$ flux from ridge soil was generally low. In the PM plots, however, a significant increase in the $\mathrm{N}_{2} \mathrm{O}$ flux was observed from February to March 2010 during the lettuce cultivation, of which the maximum was $263 \mu \mathrm{g} \mathrm{N} \mathrm{m}{ }^{-2} \mathrm{~h}^{-1}$. Other slight and temporal increases in the $\mathrm{N}_{2} \mathrm{O}$ flux after fertilization were occasionally observed throughout the experimental period.

In the OF plots, the soil $\mathrm{NH}_{4}{ }^{+}-\mathrm{N}$ content increased during the winter lettuce cultivation periods, of which the maxima reached 199 and $127 \mu \mathrm{g} \mathrm{N} \mathrm{g} \mathrm{soil}{ }^{-1}$ in 2010 and 2011, respectively. The increase in the soil $\mathrm{NH}_{4}^{+}$$\mathrm{N}$ content during the carrot cultivation was less significant in summer than in winter. In the PM plots, the soil $\mathrm{NH}_{4}{ }^{+}-\mathrm{N}$ content remained low throughout the two-year experiment. In the OF plots in 2010 , the soil $\mathrm{NO}_{3}{ }^{-} \mathrm{N}$ content increased during the winter lettuce cultivation period and remained high (higher than $250 \mu \mathrm{g} \mathrm{N} \mathrm{g}$ soil ${ }^{-1}$ ) until the harvest at the end of April. Furthermore, it was still remained high until June. From April to June 2010 , the ridge soil was still covered with the perforated black mulch film even after the lettuce harvest. Therefore, the penetration of rainfall into the ridge soil was continuously suppressed, which may have resulted in the suppression of leaching of nitrate to the underground and thus kept the $\mathrm{NO}_{3}{ }^{-} \mathrm{N}$ content in the topsoil high. The soil $\mathrm{NO}_{3}^{-}-\mathrm{N}$ content in the $\mathrm{PM}$ plots was generally lower than that in the OF plots in 2010. In 2011, the seasonal courses of the soil $\mathrm{NO}_{3}{ }^{-} \mathrm{N}$ content in the OF and PM plots were similar, with binomial peaks around March and July. In the PM plots in 2010, both the soil $\mathrm{NH}_{4}{ }^{+}$and $\mathrm{NO}_{3}{ }^{-} \mathrm{N}$ contents remained low during the winter lettuce cultivation period. Unexpectedly, a significant increase in the $\mathrm{N}_{2} \mathrm{O}$ flux during this period was observed only in the $\mathrm{PM}$ plots with low soil $\mathrm{NH}_{4}^{+}$and $\mathrm{NO}_{3}{ }^{-}-\mathrm{N}$ contents, whereas no such significant increase in the $\mathrm{N}_{2} \mathrm{O}$ flux was 
observed in the OF plots with higher soil $\mathrm{NH}_{4}^{+}$- and $\mathrm{NO}_{3}{ }^{-} \mathrm{N}$ contents. Most of labile $\mathrm{N}$ in poultry manure compost is included as uric acid, which is often decomposed and lost prior to fertilization (Murakami et al., 2011). The low $\mathrm{NH}_{4}{ }^{+}$- and $\mathrm{NO}_{3}{ }^{-} \mathrm{N}$ contents in the PM plots during this period (Fig. 1) indicate significant loss of uric acid in the applied poultry manure compost prior to the fertilization. At the same time, $\mathrm{N}$ in other various forms was also included in the applied poultry manure compost. Nitrous oxide flux from soils amended with organic fertilizer is generally high and various depending on the type of fertilizer, which indicates that various kinds of factors such as the availability of $\mathrm{C}$ and $\mathrm{N}$ in the applied organic manure are relat- ed to $\mathrm{N}_{2} \mathrm{O}$ production in the soil (Pelster et al., 2012; Rochette et al., 2008; Senbayram et al., 2012). Therefore, in this study, some of the organic compounds other than uric acid in the poultry manure compost were presumably related to the marked enhancement of $\mathrm{N}_{2} \mathrm{O}$ production during this period.

\subsection{Cumulative $\mathrm{N}_{2} \mathrm{O}$ emission}

The cumulative $\mathrm{N}_{2} \mathrm{O}$ emissions throughout the experimental period, including those from both the ridge and the furrow, are summarized in Fig. 2. The cumulative $\mathrm{N}_{2} \mathrm{O}$ emission from the entire field including both the ridge and the furrow was highest $\left(3.91 \mathrm{~kg} \mathrm{~N} \mathrm{ha}^{-1}\right)$ in the PM plots in the first cropping cycle, where a significant increase in the $\mathrm{N}_{2} \mathrm{O}$ flux from the ridge soil

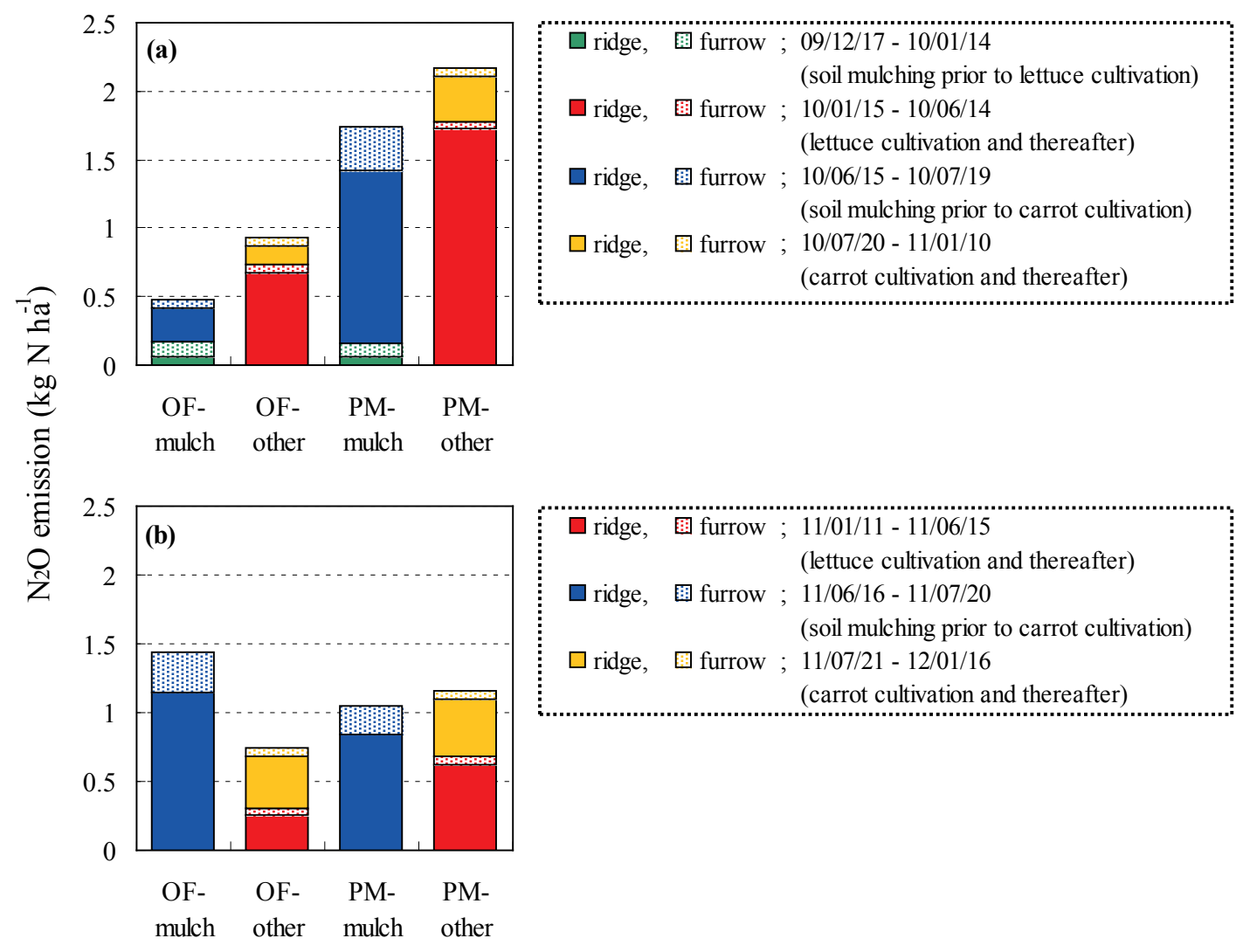

Fig. 2. Cumulative $\mathrm{N}_{2} \mathrm{O}$ emission from the field grown to lettuce and carrots from 09/12/17 to 11/01/10 (a, 1 st cropping cycle) and from 11/01/11 to 12/01/16 (b, 2nd cropping cycle).

The emissions during the periods with the imperforate mulch film and other periods (without or with perforated mulch film) are shown separately for each cropping cycle.

The $\mathrm{N}_{2} \mathrm{O}$ emission from the ridge during the periods with the imperforate mulch film is represented by the estimated emission by permeation through the mulch film. 
was observed during the winter lettuce cultivation period. In other cases, the cumulative $\mathrm{N}_{2} \mathrm{O}$ emissions in the $\mathrm{OF}$ and $\mathrm{PM}$ plots ranged from 1.41 to $2.20 \mathrm{~kg} \mathrm{~N}$ $\mathrm{ha}^{-1}$ for the first and second cropping cycles.

The contribution of the $\mathrm{N}_{2} \mathrm{O}$ flux during the period with the imperforate mulch film was lower in winter (from December 2009 to January 2010) than in summer, which ranged from 4 to $12 \%$ of the cumulative emission. In contrast, when the soil was covered with the imperforate mulch film just after fertilization in summer, the contribution of the $\mathrm{N}_{2} \mathrm{O}$ emission was high, which was $41 \%$ (PM plots in 2010), $66 \%$ (OF plots in 2011) and $48 \%$ (PM plots in 2011) of the cumulative emissions over the cropping cycle. Among these, in particular, the flux by permeation through the mulch film had a significant contribution, which was $33 \%$ (PM plots in 2010), $53 \%$ (OF plots in 2011) and $38 \%$ (PM plots in 2011) of the cumulative emissions. The contribution of the $\mathrm{N}_{2} \mathrm{O}$ emission from the furrow soil surface was comparatively low but not negligible, ranging from 8 to $13 \%$ of the cumulative emission.

An increase in soil temperature and a decrease in fluctuation of soil water content are the two major changes in environmental factors in soils caused by soil mulching. In this study, although increase in soil temperature may have temporally promoted progress of nitrification and the concurrent $\mathrm{N}_{2} \mathrm{O}$ production in the soil, the $\mathrm{N}_{2} \mathrm{O}$ production may have then rapidly decreased due to the rapid exhaustion of labile $\mathrm{N}$ in the soil available for $\mathrm{N}_{2} \mathrm{O}$ production. On the other hand, soil water content remained relatively stable (24$33 \%$ ) throughout the periods with the imperforate mulch film both in winter and in summer because both the evaporation of soil water and the penetration of rain water into the soil were restricted by the mulch film. Although $\mathrm{N}_{2} \mathrm{O}$ production by denitrification is often enhanced remarkably according to a marked increase in soil water content after heavy rain (Nishimura et al., 2005), soil mulching may have effectively prevented such enhancement. However, unfortunately, we cannot conclude how the cumulative $\mathrm{N}_{2} \mathrm{O}$ emission (or cumulative $\mathrm{N}_{2} \mathrm{O}$ production) was changed by the introduction of soil mulching practice in this study, since we did not establish plots with no soil mulching practice for comparison. The cumulative $\mathrm{N}_{2} \mathrm{O}$ emission obtained in this study should be evaluated again in future studies in comparison with the emission levels from fields with no soil mulching practice.

In this study, the amounts of $\mathrm{N}$ fertilizer differed between the OF and PM plots, and also between the first and second cropping cycles. In addition, various types of $\mathrm{N}$ compounds were included in the applied organic fertilizers. Therefore, a detailed discussion on the comparison among the treatments or on the interannual variation in $\mathrm{N}_{2} \mathrm{O}$ emission may not be possible in this study. The effects of various organic matter applications on $\mathrm{N}_{2} \mathrm{O}$ emission should also be investigated in detail in future studies.

\section{Conclusion}

In a two-year experiment in a field grown to lettuce and carrots, we quantified $\mathrm{N}_{2} \mathrm{O}$ emission during soil mulching practice and its contribution to the cumulative emission. When the soil was covered with an imperforate mulch film just after fertilization in summer, the $\mathrm{N}_{2} \mathrm{O}$ emission during the practice had a significant contribution, ranging from 41 to $66 \%$ of the cumulative emission. The $\mathrm{N}_{2} \mathrm{O}$ flux by permeation through the mulch film had a particularly high contribution, ranging from 33 to $53 \%$ of the cumulative emission. The $\mathrm{N}_{2} \mathrm{O}$ flux from the furrow soil surface was comparatively low.

\section{References}

Akiyama, H., Yan, X., and Yagi, K., 2006: Estimations of emission factors for fertilizer-induced direct $\mathrm{N}_{2} \mathrm{O}$ emissions from agricultural soils in Japan: Summary of available data. Soil Science and Plant Nutrition, 52, 774-787.

Bouwman, A. F., 1990: Exchange of greenhouse gases between terrestrial ecosystems and the atmosphere. In Soils and the Greenhouse Effect (ed. by Bouwman, A. F.). John Wiley \& Sons Ltd., Chichester, UK, pp. 61-127.

De Klein, C., Novoa, R. S. A., Ogle, S., Smith, K. A., Rochette, P., Wirth, T. C., McConkey, B. G., Mosier, R., and Rypdal, K., 2006: $\mathrm{N}_{2} \mathrm{O}$ emissions from managed soils, and $\mathrm{CO}_{2}$ emissions from lime and urea application. In 2006 IPCC Guidelines for National Greenhouse Gas Inventories, Volume 4: Agriculture, Forestry and Other Land Use (ed. by Eggleston, H. S., Buendia, L., Miwa, K., Ngara, T., and Tanabe, K.). Institute for Global Environmental Strategies, Hayama, Japan, pp. 11.1-11.54.

Forster, P., Ramaswamy, V., Artaxo, P., Berntsen, T., 
Betts, R., Fahey, D. W., Haywood, J., Lean, J., Lowe, D. C., Myhre, G., Nganga, J., Prinn, R., Raga, G., Schulz, M., and Van Dorland, R., 2007: Changes in atmospheric constituents and in radiative forcing. In: Climate Change 2007: The Physical Science Basis. Contribution of Working Group I to the Fourth Assessment Report of the Intergovernmental Panel on Climate Change (ed. by Solomon, S., Qin, D., Manning, M., Chen, Z., Marquis, M., Averyt, K. B., Tignor, M., and Miller, H. L.) . Cambridge University Press, Cambridge, UK, pp. 131-234.

Hayashi, T., Hikasa, Y., and Sakamoto, N., 2004: Nitrous oxide emission from greenhouse fields in Hokkaido and methods to reduce the emissions. Japanese Journal of Soil Science and Plant Nutrition, 75, 575-582. (In Japanese with English Summary)

Hutchinson, G. L., and Davidson, E. A., 1993: Processes for production and consumption of gaseous nitrogen oxides in soil. In Agricultural Ecosystem Effects on Trace Gases and Global Climate Change (ed. by Rolston, D, E., Harper, L. A., Mosier, A. R., and Duxbury, J. M.) . ASA, CSSA, and SSSA, Madison, WI, pp. 79-93.

Katan, J., and Devay, J. E. (ed), 1991: Soil Solarization. CRC Press, Boca Raton, FL, pp. 1-267.
Murakami, K., Hara, M., Kondo, T., and Hashimoto, Y., 2011. Increased total nitrogen content of poultry manure by decreasing water content through composting processes. Soil Science and Plant Nutrition, 57, 705-709.

Nishimura, S., Sawamoto, T., Akiyama, H., Sudo, S., Cheng, W., and Yagi, K., 2005. Continuous, automated nitrous oxide measurements from paddy soils converted to upland crops. Soil Science Society of America Journal, 69, 1977-1986.

Nishimura, S., Komada, M., Takebe, M., Yonemura, S., and Kato, N., 2012: Nitrous oxide evolved from soil covered with plastic mulch film in horticultural field. Biology and Fertility of Soils, 48, 787-795.

Pelster, D. E., Chantigny, M. H., Rochette, P., Angers, D. A., Rieux, C., and Vanasse, A., 2012. Nitrous oxide emissions respond differently to mineral and organic nitrogen sources in contrasting soil types. Journal of Environmental Quality, 41, 427-435.

Rochette, P., Angers, D. A., Chantigny, M. H., Gagnon, B., and Bertrand, N., 2008: $\mathrm{N}_{2} \mathrm{O}$ fluxes in soils of contrasting textures fertilized with liquid and solid dairy cattle manures. Canadian Journal of Soil Science, 88, 175-187.

Senbayram, M., Chen, R., Budai, A., Bakken, L., and Dittert, K., 2012. $\mathrm{N}_{2} \mathrm{O}$ emission and the $\mathrm{N}_{2} \mathrm{O} /\left(\mathrm{N}_{2} \mathrm{O}\right.$ $+\mathrm{N}_{2}$ ) product ratio of denitrification as controlled by available carbon substrates and nitrate concentrations. Agriculture, Ecosystems \& Environment, 147, 4-12. 